\title{
Boost customer loyalty with online support: the case of mobile telecoms providers
}

Citation for published version (APA):

van Riel, A. C. R., Liljander, V. M., Lemmink, J. G. A. M., \& Streukens, A. C. P. (2003). Boost customer loyalty with online support: the case of mobile telecoms providers. METEOR, Maastricht University School of Business and Economics. METEOR Research Memorandum No. 014

https://doi.org/10.26481/umamet.2003014

Document status and date:

Published: 01/01/2003

DOI:

10.26481/umamet.2003014

Document Version:

Publisher's PDF, also known as Version of record

\section{Please check the document version of this publication:}

- A submitted manuscript is the version of the article upon submission and before peer-review. There can be important differences between the submitted version and the official published version of record.

People interested in the research are advised to contact the author for the final version of the publication, or visit the DOI to the publisher's website.

- The final author version and the galley proof are versions of the publication after peer review.

- The final published version features the final layout of the paper including the volume, issue and page numbers.

Link to publication

\footnotetext{
General rights rights.

- You may freely distribute the URL identifying the publication in the public portal. please follow below link for the End User Agreement:

www.umlib.nl/taverne-license

Take down policy

If you believe that this document breaches copyright please contact us at:

repository@maastrichtuniversity.nl

providing details and we will investigate your claim.
}

Copyright and moral rights for the publications made accessible in the public portal are retained by the authors and/or other copyright owners and it is a condition of accessing publications that users recognise and abide by the legal requirements associated with these

- Users may download and print one copy of any publication from the public portal for the purpose of private study or research.

- You may not further distribute the material or use it for any profit-making activity or commercial gain

If the publication is distributed under the terms of Article $25 \mathrm{fa}$ of the Dutch Copyright Act, indicated by the "Taverne" license above, 


\section{BOOST CUSTOMER LOYALTY WITH ONLINE SUPPORT: THE CASE OF MOBILE TELECOMMS PROVIDERS}

Allard van Riel ${ }^{1 *}$, Veronica Liljander**, Jos Lemmink*** and Sandra Streukens****

* Assistant Professor, *** Professor and Chair of the Department, **** Doctoral Candidate, all at Maastricht University, Faculty of Economics and Business Administration, Department of Marketing, P.O. Box 616, NL-6200 MD Maastricht, the Netherlands.

** Acting Professor and Head of the Department, Swedish School of Economics and Business Administration, Department of Marketing and Corporate Geography, P.O. Box 479, FIN-00101 Helsinki, Finland. 


\title{
BOOST CUSTOMER LOYALTY WITH ONLINE SUPPORT: THE CASE OF MOBILE TELECOMMS PROVIDERS
}

\begin{abstract}
The paper explores the effect of customer satisfaction with online supporting services on loyalty to providers of an offline core service. Supporting services are provided to customers before, during or after the purchase of a tangible or intangible core product, and have the purpose of enhancing or facilitating the use of this product. The Internet has the potential to dominate all other marketing channels when it comes to the interactive and personalized communication that is considered quintessential for supporting services. Our study shows that the quality of online supporting services powerfully affects satisfaction with the provider and customer loyalty through its effect on online value and enjoyment. Managerial implications are provided.
\end{abstract}

Keywords: Customer Support, Service Quality, Satisfaction, Loyalty, Online Services, and Consumer Behavior 


\section{Biographical Notes}

Allard van Riel is an assistant professor of logistics in the department of marketing at Maastricht University. He holds a degree in Philosophy from the University of Amsterdam and has been active in educational publishing for almost ten years. His Ph.D. research focused on marketing decision-making under uncertainty in the area of IT-based service innovation (2002). He published articles on services marketing in the Journal of Service Research and The International Journal of Service Industry Management and contributed several chapters to books.

Veronica Liljander is acting professor of marketing and head of the department of marketing and corporate geography at the Swedish School of Economics and Business Administration in Helsinki, Finland. She has published articles on service quality and customer relationships in scientific journals and in edited books, and is on the editorial board of the European Journal of Marketing, the International Journal of Service Industry Management, and the International Journal of Internet Marketing and Advertising. Between July 2000 and July 2001 she was a visiting scholar at Maastricht University, Maastricht Academic Center for Research in Services (MAXX).

Jos Lemmink is professor and chairman of the department of marketing at Maastricht University. He holds a degree in Business Administration from the University of Groningen and a Ph.D. from the University of Limburg. He was a market researcher for the Dutch Postal Services and Telecommunications for four years and a visiting professor at the University of Southern Queensland (Australia). He published extensively on quality management and modeling. His research interests concern service management and marketing, analyses of service processes and marketing and new media. 
Sandra Streukens is a doctoral candidate in the department of marketing at Maastricht University. She holds a degree in Business Economics and Quantitative Economics from Maastricht University. Her research interests concern service quality investments, customer equity, and marketing research methods and techniques. 


\section{Introduction}

Due to an increase in the complexity of consumer products and services, and a simultaneous (and possibly related) decline in user-friendliness and reliability [1], customers require more and more support from their suppliers and service providers [1, 2, 3, 4]. Having become more aware of their rights, customers also demand and expect high quality support. For firms, setting up and maintaining high quality customer support systems is expensive, but it can lead to a number of benefits that offset the costs. Sustainable competitive advantage can be built by investing in the quality of supporting services $[5,6]$, which potentially leads to increased customer satisfaction and loyalty [7]. Although the precise relationship between customer satisfaction with supporting services and loyalty to their providers remains to be determined [e.g. 8], satisfied customers are generally considered more loyal than dissatisfied customers [9, 10], while increased loyalty is often associated with greater overall profitability $[11,12,13]$. Apart from increased customer satisfaction and loyalty, several other potential benefits of high quality support have been identified. Providing high quality support helps companies to differentiate themselves from their competitors $[14,15]$, which can be especially important for providers of relatively standardized services that are increasingly being perceived as commodities [16]. High quality support may also justify a higher price setting for the core product or service [11]. Furthermore, high quality supporting services can directly generate important revenues for companies, e.g. through the sale of subscriptions to updates, or the sale of upgrades and complementary products and services $[3,17]$. Finally, extensive helpdesks can increase the adoption rate and success of entirely new services. Little doubt remains that offering high quality support can directly or indirectly contribute to the bottom-line of many firms [18].

The Internet has been identified as a very promising channel for supporting services, as it is well suited for communication and information exchange, which are key components of nearly 
all supporting services [19]. Firms have developed various forms of online support, often complementing, sometimes substituting or extending their existing services. Customers expect similar quality levels from these electronically offered supporting services as from their traditional counterparts [20]. Still, many online services do not seem to be designed in a way that appeals to customers. Nor does their design maximize their benefits [21, 22]. In spite of these observations, and in spite of the potential economic importance of online support, very little research has been carried out in this area. Specific research on online support is needed for a number of reasons. First, substantial differences between online and traditional service encounters have been identified [16, 22, 23, 24, 25], the most obvious one being that the user interface of online services replaces the traditional servicescape $[26,27]$ and largely substitutes interaction with service staff. Contrary to what is true for traditional services, to online customers 'high quality' may actually mean not having to interact with staff at all [23, 28]. Second, traditional service research has mainly focused on customer evaluations of the core service and associated cognitive, affective and behavioral consequences [11, 29, 30]. Considerably less attention has been paid to the conceptualization and analysis of the quality of supporting services. Supporting services have a number of unique features, which may play an important role in the creation of expectations and customer satisfaction and the development of behavioral intentions, such as repurchasing and word of mouth behavior, towards the core offer as well as towards the provider of the full service package [31]. Although some research exists on consumer evaluations of self-service technologies [16, 23, 32, 33], or e-services [25, 34, 35], there is a general lack of research related to the electronic delivery of supporting services [36], or about how customers perceive the representation of the provider of a service by a machine [37]. Research is thus needed with respect to the impact of technology on various customer responses, such as perceived service quality, value, satisfaction and loyalty [24, 35, 38]. A better understanding of how customers evaluate online support and develop behavioral 
intentions as a result of these evaluations will help companies to improve their online support offering and maximize customer value.

The objective of the present study is therefore to investigate 1) determinants of satisfaction with online supporting services and 2) the relative importance of satisfaction with online support on the one hand and with the offline core service on the other in creating loyalty to the service provider. We have structured the paper as follows. First, existing theory is reviewed with respect to supporting services, online service quality and customer responses. Second, propositions are formulated and tested in an empirical study of online customer support by mobile telecommunication service providers. The paper concludes with a discussion of the results, managerial implications and directions for future research.

\section{Review of the Literature}

\section{Definition of Online Support}

Supporting services have been conceptualized as customer service or customer support [39], product support $[3,22]$, or as technical support [4], and can be conceptualized productively starting from the dichotomy between core and peripheral services. In most cases, a core product or service can be distinguished, sales of which are a major reason for the company to be in the market. This core product is often supplemented by various peripheral services [22], forming the 'augmented product' [40]. The main purpose of the peripheral services is to increase the value of the total offer. Peripheral services have been subdivided into facilitating and enhancing services [40], or facilitating and supporting services [41]. Loomba [1 p.4] suggests that support comprises all activities, which "ensure that consumers continue to obtain trouble-free use of a product over its life cycle." Support occurs before, during or after the purchase of tangible or intangible core products $[42,43]$, and can take the form of documentation, installation, user training, field services such as product upgrades, maintenance and repair, and warranties $[1,17$, 
$43,44,45]$. With the purpose of preliminarily defining online support, we combine definitions of electronic services (e-services) and traditional customer service. Thus, online supporting services include all aspects of online service, i.e. the total of online cues and encounters [25], occurring before, during or after the online or offline delivery of a core product or service, provided in order to ensure that customers obtain trouble-free product use and gain support in case of problems and questions.

\section{Characteristics of Online Support}

The Internet has been identified as a promising channel for supporting services, as it is well suited for communication and information exchange, which is essential to virtually all supporting services [19]: almost unlimited amounts of information can be made available in real-time, with a high degree of efficiency [46], substantially decreasing the need for interaction with costly human staff. Potential benefits of providing information online are that documentation can be customized to specific regions, can contain more and richer information than print copies, and can contain more and better pictures and even interactive video sequences. Online documentation can more easily be kept up-to-date than print materials, while the quality of instructions can be improved based on customer feedback. Services are globally accessible, 365/365 and 24/24. Global support can be organized centrally, eliminating the need for numerous local offices. Firms can also deal with their customers directly, decreasing the need for expensive intermediaries, and at the same time improving the quality of market intelligence, while building learning relationships with their customers [38].

\section{Development of Propositions}

\section{Value, Enjoyment and Satisfaction}

The relationships between customer evaluations of supporting services and their attitude towards a provider will be explored from the perspective of the Quality-Satisfaction-Loyalty 
chain [47]. In this model, perceived service quality positively affects customer satisfaction. Satisfaction is considered a key antecedent of a whole battery of desired behavioral intentions $[40,48]$, such as recommendation of the provider, repurchase behavior and a preference for a particular provider compared to its competitors [see e.g. 10]. In a relationship context, customer satisfaction results from a comprehensive evaluation of the complete service offer $[49,50]$. Since the core product or service is the fundamental reason why the customer deals with a company, we expect:

$\mathbf{P}_{1}$ : $\quad$ There will be a positive relationship between customer satisfaction with the core service and loyalty to the provider.

Supporting services are part of the complete service offer, and in line with previous research we expect that customer responses to the quality of supporting services will be similar to those with respect to the quality of the core service [e.g. 51, 52] and will thus lead to customer satisfaction and loyalty to the provider:

$\mathbf{P}_{2}$ : There will be a positive relationship between customer satisfaction with online support and loyalty to the provider.

Loyalty to the provider will be a function of satisfaction with online and core service, but since no previous theories exist in this respect, we do not develop a proposition about the precise form of this functional relationship.

In services marketing the customer satisfaction concept has been used rather ambiguously. It has recently been defined as a pleasurable fulfillment of a need or goal [53]. This definition implies on the one hand that it is the result of an evaluation, or a comparison of received benefits with expectations previously held by the customer, but on the other hand it also refers to an affective dimension. In line with previous research [54], we expect: 
$\mathbf{P}_{3}$ : A direct positive relationship exists between the extent to which customers perceive online supporting services as valuable and their satisfaction with these services.

We thus conceptualize perceived value as an antecedent of customer satisfaction [55]. In the literature, value has been defined as a) low price b) quality compared to price, c) all that I get for all that I give, or d) whatever I want in a service [56]. Since many supporting services are offered free of charge, their perceived value will most likely be based on the last alternative. Since experienced enjoyment of using self-service technologies has been shown to be an important antecedent in customer evaluations of technology [32, 57], which also leads to satisfaction $[58,59]$, we expect:

P4: A direct positive relationship exists between the extent to which customers perceive online supporting services as enjoyable and their satisfaction with these services.

\section{E-Service Quality Dimensions}

Service quality drives customer satisfaction and loyalty. Service quality, and electronic service quality (e-service quality) in particular, are conceptualized as multidimensional constructs. In the following, we take the idea of the dualistic nature of satisfaction one step further and propose that perceived service quality in some dimensions will act as an antecedent of value, whereas perceived service quality in other dimensions will act as an antecedent of pleasure, or enjoyment [e.g. 51]. There is a lack of published conceptual and empirical studies on online quality in different service contexts $[25,28,35,60,61]$ and no studies discuss the perceived quality of online supporting services. Most e-service research currently relates to an ecommerce context, but there is no consensus about the dimensionality of e-service quality and the character and number of factors vary substantially between studies. The most extensive 
conceptualization to date is the e-quality framework proposed by Zeithaml et al. [25] for online purchases, consisting of eleven e-service quality sub-dimensions that can partly be related back to SERVQUAL $[62,63,64]$. In another recent study [65] eight factors were used to explain customer loyalty in an online retailing environment, whereas authors of another study [66] reduced a large number of variables to fourteen items that loaded on four factors. To a certain extent the number of factors is arbitrary and much overlap can be observed between the factors recently identified by various research teams, depending on the type of service that is studied. Based upon theoretical considerations and a review of previous studies a decision was made to distinguish five e-quality dimensions. It has been argued that consumers use similar quality dimensions no matter which type of service is evaluated on the Internet [25]. In the following we make an attempt to identify dimensions that apply universally to online services.

\section{Usability}

The first e-service quality dimension we propose is the usability of the user interface. Here we refer to all functional aspects of online services, and as a consequence usability comprises a number of previously identified e-quality dimensions. A first requirement for using services is that customers must be able to find the support website and to access it [25, 60]. Once the services are found and accessed, customers will need to navigate through the electronic servicescape, or e-scape. The quality dimension ease of navigation refers to the perceived amount of effort needed to find whatever the customer searches on the site. Ease of navigation requires that functions assisting the customer are available; help functions, search engines, etc. To be utilizable the service should also be perceived reliable [25], which requires correct technical functioning, accuracy of links and supply of correct i.e. complete and up-to-date information. Seamless, consistent and reliable interactions with the site are of increasing importance to users of the Internet [28]. Efficiency [25] also contributes to the usability of the services, since it reflects the ease of use and logical structure of the web site. A general rule in 
this respect seems to be that customers should never need more than two clicks in order to get to what they need. Basic information, such as frequently asked questions (FAQ) and a contact address should be easy to find and there should be no need to provide extensive personal information each time support is needed. Information should be logically structured, easy to understand and presented in reasonable chunks. Since the usability of the services does not intrinsically contribute to the value of the services, although a lack of usability leads to distress, we expect:

P5: $_{5}$ There will be a direct positive relationship between perceived usability of the online supporting services and enjoyment.

\section{E-scape Design}

Functionality of the website is one thing, but the customer should also feel comfortable, when using the service. From this perspective all tangible or visible aspects of the user interface can be compared with the so-called servicescape [26] of brick-and-mortar firms. Therefore the second e-quality dimension we propose relates to the aesthetic experiences of the customer [23, 25], while navigating the e-scape. A well-organized, clearly readable overview of available services as well as appealing colors will contribute to customer enjoyment, and we expect:

P6 $_{6}$ There will be a direct positive relationship between perceived quality of the escape and enjoyment.

Functionality and aesthetics are thus expected to contribute mainly to the enjoyment of the customer, whereas they are not expected to have a major impact on the perceived intrinsic value of the services. Other aspects of supporting services can be expected to contribute little to the enjoyment of the customer, but instead augment the perceived benefits of using the services. 


\section{Customization}

A third dimension of e-service quality we propose is customization. This dimension covers to what extent and how easily the site accommodates customers' preferences and how well it is designed to appeal to the user group [25]. We suggest to include the dimension flexibility [25], being defined as the extent to which the provider offers a range of service options. If this range is broad enough, the firm actually allows the customer to choose their preferred option, which comes very close to a customized solution. Examples of areas where the provider could offer flexibility are communication, payment, and delivery and return methods. Flexibility is derived from the ability of the service worker to adapt the service in order to meet customer needs [28]. Customization can e.g. be achieved by creating personalized websites that utilize previously collected information about preferences, past purchases, and navigation behavior. Since customization is intended to create added value to the customer, we expect:

$\mathbf{P}_{7}$ : There will be a direct positive relationship between the extent customers perceive the online services to be adapted to their unique history and requirements (customization) and the perceived value of these services.

\section{Assurance}

A fourth dimension that can be distinguished is assurance, resulting from perceptions of security, safety and trust. Security is the extent to which customers perceive the provider's web services to be free from intrusions by third parties, whereas privacy refers to the active maintenance of a level of confidentiality with respect to private information provided to the provider [25]. Customers expect they can trust companies to protect any personal information they may have gathered. Security and privacy are therefore closely connected to trust [34]. Trust and assurance are considered the most important drivers of e-service satisfaction and loyalty $[12,67]$ and must be considered a hygiene factor, i.e. immensely important when absent [28]. 
The effect of distrust is also presumed to be greater than the effect of trust [68]. Trust can broaden the zone of tolerance: occasional inconsistencies in service performance will not necessarily lead to distrust, if adequate explanations for the event are given and accepted [69]. In other words, the company should keep its promises [70] and provide honest and accurate information. When valuable transactions are made online, assurance will be closely related to security/privacy and providing reliable information. We expect:

$\mathbf{P}_{8}$ : $\quad$ There will be a direct positive relationship between assurance and the perceived value of the supporting services.

\section{Responsiveness}

Finally a quality dimension has been identified that, in the case of supporting services, could be expected to contribute directly to overall satisfaction. Responsiveness relates to the ability to respond quickly to requests for support $[25,28]$. In the case of supporting services, the speed with which the company reacts, provides help to problems and takes care of follow-up seems to be an essential quality. While communication in different forms is at the heart of all service interactions $[41,71]$ and an important element of online services [22], we expect the extent to which the support web site facilitates efficient and effective interaction and communication between the customer and the company to be a key satisfier:

P9: There will be a direct and positive relationship between perceived responsiveness and satisfaction with the supporting services.

We have summarized the propositions in a conceptual model that is presented in Figure 1.

[PLEASE INSERT FIGURE 1 ABOUT HERE] 


\section{Research Design and Methodology}

\section{Research Setting}

To test our propositions an empirical study was designed. We decided to study online support offered by providers of mobile telecommunication services. The European mobile telecommunications market is a good example of a nearly saturated market, where the core product has become a commodity. In this business it is extremely important to retain existing customers and supporting websites are becoming an important or even indispensable component of the overall offering. For example, to be able to use the core service, customers need a communication device. Customers, having a problem with this device, probably contact the service provider before contacting the producer. As a result, additional supporting services are expected from mobile telecommunication service providers.

On support websites, existing and new customers are addressed and informed about the company, its products, services, tariffs, shop locations, etc. Thus different forms of pre- and post- transaction support are offered. Information is also offered about innovations and upgrades. Companies provide email forums, and chatrooms as a platform for learning, discussion and the exchange of experiences. They provide various supplementary services such as online SMS (Short Message Services), and WAP, and offer dial tones, logos and games for download. Furthermore, they offer customized online services with the explicit purpose of creating loyalty, such as the 'unified messaging' service from D2 (www.d2vodafone.de): one centrally stored address book which can be accessed from the Internet (for emailing), from their mobile phone, and from their personal digital assistant (PDA), which is updated automatically. D2 expects that customers, once they have installed this convenient tool will think twice before changing their provider. For the customer, the websites provide a platform where they interact with other customers and the company, get information about mobile telecommunication, support, and entertainment, whenever and wherever they need it. 


\section{Questionnaire Design and Measurement}

A structured and undisguised questionnaire was designed. The purpose of the study was revealed and detailed instructions were provided. Questions covered all identified dimensions of perceived e-service quality. Furthermore, the survey contained questions on satisfaction with the mobile telecommunication provider's online support, and satisfaction with the provider's core service. In order to measure loyalty, we adapted the four-item behavioral outcomes scale developed by Zeithaml, Parasuraman and Berry [48] for use in this particular environment and included questions on provider preference, the intentions to recommend the provider (word of mouth), to continue using this provider (loyalty) and to repurchase the same package form this provider. All variables were measured on seven-point Likert scales as self reported attitudes towards a range of statements, ranging from 'completely disagree' to 'completely agree'. All variables were measured with multi-item measures combining between two and four indicators.

\section{[PLEASE INSERT TABLE 1 ABOUT HERE]}

In Table 1 the questionnaire items are presented. The questionnaire was pre-tested offline. Content, wording, sequence, layout, and instructions were extensively discussed and revised when necessary.

\section{Sampling}

An invitation to participate in the online survey was posted on a website accessed by users of different telecommunication service providers: the homepage of the Marketing Department of a medium-sized university in Western Europe. Students, staff and other visitors from various countries call on the site. As a result, the sample largely consisted of students having a contract with a mobile telecommunication provider or a prepaid card. Thus, a non-probability sample was used [72]. A pop-up window invited everyone accessing the website between mid July and mid August 2001 to partake in the study. Participants were rewarded with a five Euro gift 
voucher. Between mid August and mid September 2001 the questionnaire could still be accessed. Experts suggest that online surveys should be posted for at least one week, preferably two, in order to give visitors enough time to participate in the survey [73].

\section{[PLEASE INSERT TABLE 2 ABOUT HERE]}

In Table 2 an overview is presented of all mobile telecommunication service providers in the survey and the URL's where their services can be found.

\section{Analysis and Results}

The data were screened for missing values, but few were found. In those cases where this had little consequence we substituted the missing values with the mean [74]. Furthermore the distributions of values for all variables were checked for normality. In Table 3 we present correlations between all core constructs.

\section{[PLEASE INSERT TABLE 3 ABOUT HERE]}

Subsequently, the hypothesized relationships in our model were tested by means of seemingly unrelated regression (SUR). The use of SUR [75] warrants that the interrelationships among the different equations are taken into account and that prediction accuracy is optimized. The relationships hypothesized in our model are summarized in Figure 2. A Breusch-Pagan test for contemporaneous error correlation [76] was performed, and indicated that the error terms of the four equations in our system are significantly correlated. Failing to take this intercorrelatedness of the error terms into account in estimating the relationships in our model will lead to invalid results. 
The reliability measures for the constructs used in our study were presented in Table 1 . We can conclude that all constructs exhibit a high degree of reliability as all values for Cronbach's alpha exceed the recommended cut-off level of 0.70 [77].

\section{Testing of Propositions}

Table 4 contains the results of the SUR used to estimate the various parameters in our model. From the numbers presented in Table 4 we can conclude that the data supports our conceptual model. Based on the system weighted $\mathrm{R}^{2}$ we conclude that 60 per cent of the variance in the data is explained by our model.

\section{[PLEASE INSERT TABLE 4 ABOUT HERE]}

Table 5 contains the unstandardized coefficients and the accompanying t-values for the various parameters of our model. The numbers in Table 5 guide our test of the various propositions.

\section{[PLEASE INSERT TABLE 5 ABOUT HERE]}

We see that online enjoyment is significantly influenced by both usability (unstandardized coefficient $=0.19 ; \mathrm{t}$-value $=1.89)$ and $e$-scape $($ unstandardized coefficient $=0.55 ; \mathrm{t}$-value $=$ 5.35). Consequently, the data provide support for propositions 5 and 6 . Online value is only significantly influenced by customization (unstandardized coefficient $=0.79$; t-value $=8.90$ ). Thus, we accept proposition 7. As there is no empirical support for the influence of assurance on online value, we reject proposition 8 .

From the results presented in Table 5, we can also conclude that online satisfaction is significantly influenced by all three hypothesized antecedents; namely online enjoyment (unstandardized coefficient $=0.35$; $\mathrm{t}$-value $=3.72$ ), online value (unstandardized coefficient $=$ 
$0.46 ; \mathrm{t}$-value $=5.96$ ), and responsiveness (unstandardized coefficient $=0.22 ; \mathrm{t}$-value $=3.86$ ). Therefore, our data also support propositions 3, 4 and 9 respectively.

Turning to the ultimate dependent variable in our model, loyalty to the provider, we see that loyalty is both influenced by online satisfaction (unstandardized coefficient $=0.54$; $\mathrm{t}$-value $=$ 5.83) and offline satisfaction (unstandardized coefficient $=0.61$; $\mathrm{t}$-value $=6.49$ ). Our data thus support propositions 1 and 2. A Wald-test was conducted to investigate whether online and offline satisfaction had statistically different impacts on loyalty. As the Wald-test appeared to be highly insignificant we can conclude that the effects of online satisfaction and offline satisfaction on loyalty to the provider are equal in this sample.

\section{Conclusion}

The objective of the present study was to identify antecedents of satisfaction with online supporting services, and to determine the relative effects of satisfaction with online supporting services on the one hand, and with the offline core service on the other, on loyalty to the service provider. We identified five potential e-service quality dimensions that could influence customer satisfaction with the online offering. Effects on customer satisfaction of the perceived quality of the user interface in terms of its usability as well as of its more aesthetic qualities were predicted and confirmed in our study. Perhaps surprisingly we did not observe a significant effect of assurance on satisfaction. This could imply that the importance of assurance for customers of online services and loyalty to their providers has been overstated in the literature, due to a focus on the perceived risks of online transactions. Possibly, however, the participants of the survey, mainly students and university staff have an above-normal technology readiness [78], which may make them less sensitive to online security issues. Our results demonstrate that, at least to the surveyed customers of mobile telecommunication service websites, assurance is of less importance and that these consumers may take security for 
granted, especially with respect to online services provided by well-known and reputable companies such as telecommunication firms. If consumers fail to adopt online supporting services offered by telecommunication providers it is more likely to be due to lack of customization, problems with accessing the service or a badly structured e-scape. Furthermore, we observed that in the present study responsiveness had a significant direct effect on satisfaction.

Although the Internet has been widely promoted as an interactive medium, most currently offered services cannot be described as truly interactive. Customers search and retrieve information, but there are few instances where they actually enter into an active dialogue with the site. Therefore, responsiveness may currently be perceived as a fairly neutral service quality dimension. It becomes critical, however, when customers have immediate and unique problems that need immediate answers and especially when those answers are needed from an expert and not from a database of FAQ. Responsiveness could probably also be seen as a hygiene factor, where the absence or lack of responsiveness has a stronger impact on customer satisfaction than its presence. If customers provide feedback to the site, but it is ignored and no improvements can be discerned it is likely to have a strong negative effect on overall satisfaction with the site. Furthermore, we observed that in the case of mobile telecommunication service providers the perceived quality of online supporting services is tremendously important for the creation of desired behavioral intentions and loyalty. In this particular case online and offline satisfaction contributed equally to the desired effects.

\section{Managerial Implications}

These results have several implications for managers. In the case of telecommunication providers' websites, online supporting services have a major impact on overall satisfaction with the provider and may thereby affect customer retention. Offering high quality supporting 
services appears especially important in industries with an important share of young, technology ready consumers, such as the telecommunication services industry, but also in industries like IT, entertainment, etc. Research has shown that especially young telecommunication customers share provider experiences among themselves, and switching behavior is often based on wordof-mouth from peers. Our results indicate that managers need to pay special attention to varying customer support needs. It seems advisable to offer a range of customized services, or at least services that are perceived as customized. Since online support is less costly for the company than call-center services or other person-to-person contact, it is in the interest of the company to make online support an attractive alternative. Furthermore, services have to be offered through a well-designed electronic servicescape, or e-scape. Customer satisfaction clearly also depends on how enjoyable it is to use the services offered on the web site. The design of the site can add to or detract from customer enjoyment. For example, careful consideration needs to be given to the extent of distracting pop-ups, banner ads, or other features not related to the supporting service. When customers have a problem, they need to find the solution fast and efficiently. An intuitive design adds to their enjoyment, whereas a lack of it may lead to great irritation.

\section{Limitations and Suggestions for Further Research}

A number of limitations apply to the present research. A greater sample size and sample heterogeneity would have allowed us to apply more sophisticated analytical techniques and might have led to a segmentation of user groups. It must be recognized that the rather homogeneous composition of the present sample in terms of age range and occupation, as a result of the use of mainly student and academic staff as subjects, limits the scope and generalizability of our conclusions. Students must be considered a unique customer segment. Although they represent an important segment for the mobile telecommunication services industry, they may not well represent consumers in other industries. Students have a high level of technology acceptance, and may therefore have a special preference for the use of high-tech 
services, such as the web services of telecommunication providers. As a result of these preferences they may also have expectations that are distinct from other consumer segments. In spite of these considerations, students are representing an upcoming consumer segment for many services. Future research must, however, look into differences that may exist between different age groups or other customer segments. It is for example quite well possible that the role of enjoyment of using the service varies substantially between segments (young/old, what type of services they use, etc.). Furthermore, next generation mobile phones (GPRS or I-mode) are already opening up many new opportunities as a channel for online support and the value and enjoyment of receiving various supporting services through that channel should be investigated. In addition, the relative importance of different types of online support and their value-adding potential and bonding effect with customers should be investigated. Although the services may be perceived as valuable in themselves, they do not necessarily add value, or distinguish the core product from competitive offers. Finally, the validity of the outcomes of our study depends largely on the importance of online support to customers of the core service. Research is needed to investigate the relative importance customers attach to (online) support with respect to a variety of core products and services.

\section{ACKNOWLEDGEMENTS}

The authors gratefully acknowledge the original contributions of Sarah Sikorski, graduate student at Maastricht University, who wrote her master's thesis on the topic of online support, and collected the data for this study. The authors also gratefully acknowledge the constructive and helpful comments from the editor and three anonymous reviewers. 


\section{References}

1. Loomba, A.P. (1996), Linkages between Product Distribution and Service Support Functions, International Journal of Physical Distribution and Logistics Management 26 (4): 4-22.

2. Grönroos, C. (1990), Service Management and Marketing: Managing the Moments of Truth in Service Competition Lexington MA: Lexington Books.

3. Goffin, K. and New, C. (2001), Customer Support and New Product Development - an Exploratory Study, International Journal of Operations and Production Management 21 (3): 275-301.

4. Vavra, T.G. (1992), Aftermarketing: How to Keep Customers for Life through Relationship Marketing Burr Ridge IL: Business One Irwin.

5. Grönroos, C. (1990), Relationship Approach to Marketing in Service Contexts, Journal of Business Research 20 (1): 3-11.

6. Barney, J.B. (2001), Gaining and Sustaining Competitive Advantage Upper Saddle River NJ: Prentice Hall.

7. Daugherty, P.J., Ellinger, A.E. and Plair, Q.J. (1997), Using Service to Create Loyalty with Key Accounts, International Journal of Logistics Management 8 (2): 83-91.

8. Oliver, R.L. (1996), Satisfaction: A Behavioral Perspective on the Consumer New York: McGraw-Hill Companies Inc.

9. Anderson, E.W., Fornell, C. and Rust, R.T. (1997), Customer Satisfaction, Productivity, and Profitability: Differences between Goods and Services, Marketing Science 16 (2): $129-45$.

10. Dick, A.S. and Basu, K. (1994), Customer Loyalty: Towards an Integrated Conceptual Framework, Journal of the Academy of Marketing Science 22 (2): 99-113. 
11. Reichheld, F.F. and Sasser, J., W. Earl (1990), Zero Defections: Quality Comes to

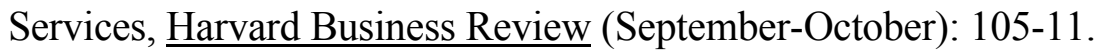

12. Reichheld, F.F. and Schefter, P. (2000), E-Loyalty: Your Secret Weapon on the Web, Harvard Business Review (July-August): 105-13.

13. Reichheld, F.F. and Teal, T. (1996), The Loyalty Effect: The Hidden Force Behind Growth, Profits and Lasting Value Boston, MA: Harvard Business School Press.

14. Normann, R. (2001), Service Management: Strategy and Leadership in Service Business New York: Wiley and Sons.

15. Van der Veeken, D.J.M. and Rutten, W.G.M.M. (1998), Logistics Service Management: Opportunities for Differentiation, International Journal of Logistics Management 9: 9198.

16. Bitner, M.J., Brown, S.W. and Meuter, M.L. (2000), Technology Infusion in Service Encounters, Journal of the Academy of Marketing Science 28 (1): 138-49.

17. Goffin, K. (1999), Customer Support - a Cross-Industry Study of Distribution Channels and Strategies, International Journal of Physical Distribution and Logistics Management 29 (6): 374-97.

18. Mathe, H. and Shapiro, R.D. (1990), Managing the Service Mix: After Sale Service for Competitive Advantage, International Journal of Logistics Management 1 (1): 44-50.

19. Peterson, R.A., Balasubramanian, S. and Bronnenberg, B.J. (1997), Exploring the Implications of the Internet for Consumer Marketing, Journal of the Academy of Marketing Science 25 (4): 329-46.

20. Bitner, M.J. (2001), Service Technology: Opportunities and Paradoxes, Managing Service Quality 11 (6): 375-79. 
21. Bradshaw, D. and Brash, C. (2001), Managing Customers in the E-Business World: How to Personalise Computer Relationships for Increased Profitability, International Journal of Retail \& Distribution Management 29 (12): 520-30.

22. Grönroos, C., Heinonen, F., Isoniemi, K. and Lindholm, M. (2000), The Netoffer Model: A Case Example from the Virtual Marketspace, Management Decision 38 (4): $243-52$.

23. Meuter, M.L., Ostrom, A.L., Roundtree, R.I. and Bitner, M.J. (2000), Self-Service Technologies: Understanding Customer Satisfaction with Technology-Based Service Encounters, Journal of Marketing 64 (July): 50-64.

24. Parasuraman, A. and Grewal, D. (2000), The Impact of Technology on the QualityValue-Loyalty Chain: A Research Agenda, Journal of the Academy of Marketing Science 28 (1): 168-74.

25. Zeithaml, V.A., Parasuraman, A. and Malhotra, A. (2000), A Conceptual Framework for Understanding E-Service Quality: Implications for Future Research and Managerial Practice, Working Paper, Report Nr. 00-115, Cambridge, MA: Marketing Science Institute.

26. Bitner, M.J. (1992), Servicescapes: The Impact of Physical Surroundings on Customers and Employees, Journal of Marketing 56 (2): 57-71.

27. Eroglu, S.A., Machleit, K.A. and Davis, L.M. (2001), Atmospheric Qualities of Online Retailing: A Conceptual Model and Implications, Journal of Business Research 54: 17784.

28. Dilts, D.M. and Lyth, D.M. E-Commerce and E-Service Quality. Service Quality in the New Economy: Interdisciplinary and International Dimensions 90-97 (2000) 
29. Parasuraman, A., Berry, L.L. and Zeithaml, V.A. (1985), A Conceptual Model of Service Quality and Its Implications for Future Research, Journal of Marketing 49 (Fall): 41-50.

30. Iacobucci, D., Ostrom, A.L., Braig, B.M. and Bezjian-Avery, A. (1996), A Canonical Model of Consumer Evaluations and Theoretical Bases of Expectations, Advances in Services Marketing and Management: Research and Practice 5 (1996): 1-44.

31. Javalgi, R.G. and Moberg, C.R. (1997), Service Loyalty: Implications for Service Providers, Journal of Services Marketing 11 (3): 165-79.

32. Dabholkar, P.A. (1996), Consumer Evaluations of New Technology-Based Self-Service Options: An Investigation of Alternative Models, International Journal of Research in Marketing 13 (1): 29-51.

33. Meuter, M.L., Bitner, M.J. and Ostrom, A.L. (2002), Adoption of Self-Service Technologies,

34. Liljander, V., van Riel, A.C.R. and Pura, M. (2002), Customer Satisfaction with EServices: The Case of an on-Line Recruitment Portal. In: Jahrbuch Dienstleistungsmanagement 2002 - Electronic Services -, M. Bruhn and B. Stauss (eds.). Wiesbaden: Gabler, pp. 407-32.

35. Van Riel, A.C.R., Liljander, V. and Jurriëns, P. (2001), Exploring Consumer Evaluations of E-Services: A Portal Site, International Journal of Service Industry Management 12 (4): 359-77.

36. Novak, T.P., Hoffman, D.L. and Yung, Y.-F. (2000), Measuring the Consumer Experience in Online Environments: A Structural Modeling Approach, Marketing Science 19 (1): 22-42.

37. Selnes, F. and Hansen, H. (2001), The Potential Hazard of Self Service in Developing Customer Loyalty, Journal of Service Research 4 (2): 79-90. 
38. Rust, R.T. and Lemon, K.N. (2001), E-Service and the Consumer, International Journal of Electronic Commerce 5 (3): 85-101.

39. Wetzels, M., De Ruyter, K. and Van Birgelen, M. (1998), Marketing Service Relationships: The Role of Commitment, Journal of Business and Industrial Marketing 13 (4/5): 406-23.

40. Lovelock, C.H. and Wright, L.K. (2002), Principles of Service Marketing and Management Upper Saddle River, NJ: Prentice Hall.

41. Grönroos, C. (2000), Service Management and Marketing: A Customer Relationship Management Approach New York: John Wiley and Sons.

42. LaLonde, B.J. and Zinszer, P.H. (1976), Customer Service: Meaning and Measurement Chicago, IL: The Council of Physical Distribution Management.

43. Stock, J.R. and Lambert, D.M. (2001), Strategic Logistics Management Boston, MA: McGraw-Hill Irwin.

44. Lele, M.M. (1997), After-Sales Service - Necessary Evil or Strategic Opportunity?, Managing Service Quality 7 (3): 141-45.

45. Goffin, K. (1998), Evaluation Customer Support During New Product Development - an Exploratory Study, Journal of Product Innovation Management 15: 42-56.

46. Adamic, L.A. and Huberman, B.A. (2000), The Nature of Markets in the World Wide Web, Quarterly Journal of Electronic Commerce 1 (1): 5-12.

47. Anderson, E.W. and Sullivan, M.W. (1993), The Antecedents and Consequences of Customer Satisfaction for Firms, Marketing Science 12 (2): 125-43.

48. Zeithaml, V.A., Berry, L.L. and Parasuraman, A. (1996), The Behavioral Consequences of Service Quality, Journal of Marketing 60 (April): 31-46. 
49. Liljander, V. and Strandvik, T. (1995), The Relation between Service Quality, Satisfaction and Intentions. In: Managing Service Quality, P. Kunst and J. Lemmink (eds.). London: Paul Chapman Publishing, pp. 45-63.

50. Bateson, J.E.G. (1991), Managing Services Marketing Orlando: The Dryden Press.

51. Brady, M.K. and Cronin Jr., J.J. (2001), Customer Orientation. Effects on Customer Service Perceptions and Outcome Behaviors, Journal of Service Research 3 (3): 241-51.

52. Sweeney, J.C., Soutar, G.N. and Johnson, L.W. (1999), The Role of Perceived Risk in the Quality-Value Relationship: A Study in a Retail Environment, Journal of Retailing 75 (1): 77-105.

53. Oliver, R.L. (1999), Whence Customer Loyalty?, Journal of Marketing 63 (Special Issue): $33-44$.

54. Parasuraman, A. (1997), Reflections on Gaining Competitive Advantage through Customer Value, Journal of the Academy of Marketing Science 25 (2): 154-61.

55. Oliver, R.L. (1996), Varieties of Value in the Consumption Satisfaction Response. In: Advances in Consumer Research, J. G. Lynch Jr. (eds.). pp. 143-47.

56. Zeithaml, V.A. (1988), Consumer Perceptions of Price, Quality, and Value: A MeansEnd Model and Synthesis of Evidence, Journal of Marketing 52 (July): 2-22.

57. Dabholkar, P.A. and Bagozzi, R.P. (2002), An Attitudinal Model of Technology-Based Self-Service: Moderating Effects of Consumer Traits and Situational Factors, Journal of the Academy of Marketing Science 30 (3): 184-201.

58. Oliver, R.L., Rust, R.T. and Varki, S. (1997), Customer Delight: Foundations, Findings, and Managerial Insight, Journal of Retailing 73 (3): 311-36.

59. Liljander, V. and Strandvik, T. (1997), Emotions in Service Satisfaction, International Journal of Service Industry Management 8 (2): 148-69. 
60. Cox, J. and Dale, B.G. (2001), Service Quality and Ecommerce: An Exploratory Analysis, Managing Service Quality 11 (2): 121-31.

61. Kaynama, S.A. and Black, C.I. (2000), A Proposal to Assess the Service Quality of Online Travel Agencies: An Exploratory Study, Journal of Professional Services Marketing 21 (1): 63-88.

62. Parasuraman, A., Zeithaml, V.A. and Berry, L.L. (1988), Servqual: A Multiple Item Scale for Measuring Consumer Perceptions of Service Quality, Journal of Retailing 64 (1): $12-40$.

63. Parasuraman, A., Berry, L.L. and Zeithaml, V.A. (1991), Refinement and Reassessment of the Servqual Scale, Journal of Retailing 67 (4): 420-50.

64. Parasuraman, A., Zeithaml, V.A. and Berry, L.L. (1994), Reassessment of Expectations as a Comparison Standard in Measuring Service Quality: Implications for Further Research, Journal of Marketing 58 (January 1994): 111-24.

65. Srinivasan, S.S., Anderson, R.E. and Ponnavolu, K. (2002), Customer Loyalty in ECommerce: An Exploration of Its Antecedents and Consequences, Journal of Retailing 78 (1): 41-51.

66. Wolfinbarger, M. and Gilly, M.C. (2001), Shopping Online for Freedom, Control, and Fun, California Management Review 43 (Winter): 34-55.

67. Urban, G.L., Sultan, F. and Qualls, W.J. (2000), Placing Trust at the Center of Your Internet Strategy, Sloan Management Review 42 (1): 39-48.

68. Singh, J.V. and Sirdeshmukh, D. (2000), Agency and Trust Mechanisms in Consumer Satisfaction and Loyalty Judgments, Journal of the Academy of Marketing Science 28 (1): $150-67$.

69. Berry, L.L. (1999), Discovering the Soul of Service New York: The Free Press. 
70. Bitner, M.J. (1995), Relationship Marketing: It's All About Promises, Journal of the Academy of Marketing Science 23 (4): 246-51.

71. Ford, W.Z. (1998), Communicating with Customers: Service Approaches, Ethics and Impact Cresskill, NJ: Hampton Press Inc.

72. Churchill Jr., G.A. (1995), Marketing Research: Methodological Foundations Fort Worth, TX: The Dryden Press.

73. Ilieva, J., Baron, S. and Healy, N.M. (2002), Online Surveys in Marketing Research: Pros and Cons, International Journal of Market Research 44 (3): 361-76.

74. Hair, J.F., Anderson, R.E., Tatham, R.L. and Black, W.C. (1998), Multivariate Data Analysis Upper Saddle River, NJ: Prentice Hall, Inc.

75. Zellner, A. (1962), An Efficient Method of Estimating Seemingly Unrelated Regressions and Tests of Aggregation Bias, Journal of the American Statistical Association 57: 500-09.

76. Breusch, T. and Pagan, A. (1980), The Lm Test and Its Applications to Model Specification in Econometrics, Review of Economic Studies 47: 239-54.

77. Nunnally, J.C. and Bernstein, I.H. (1994), Psychometric Theory New York: McGrawHill Book Company.

78. Parasuraman, A. (2000), Technology Readiness Index (TRI): A Multiple-Item Scale to Measure Readiness to Embrace New Technologies, Journal of Service Research 2 (4): $307-20$. 
Table 1: Composition and Reliability of the Scales

\begin{tabular}{|c|c|c|c|}
\hline Scale & Items & Item Mean & $\begin{array}{l}\text { Reliability } \\
\text { (Alpha) }\end{array}$ \\
\hline \multirow[t]{7}{*}{ Usability } & Easy to get access to site & 4.60 & .81 \\
\hline & Links are problem-free & 4.70 & \\
\hline & Pages download quickly & 4.60 & \\
\hline & Site is user friendly & 4.30 & \\
\hline & Navigation is easy & 4.64 & \\
\hline & Searching is easy & 4.36 & \\
\hline & Easy to find your way & 4.50 & \\
\hline \multirow[t]{5}{*}{ E-scape } & Page design is intuitive & 4.18 & .91 \\
\hline & Info attractively displayed & 4.14 & \\
\hline & Info well displayed & 4.16 & \\
\hline & Layout and Colors appeal & 4.37 & \\
\hline & Satisfied with design & 4.40 & \\
\hline \multirow[t]{3}{*}{ Responsiveness } & Easy to get in touch & 4.43 & .89 \\
\hline & Interested in feedback & 3.43 & \\
\hline & Reply quickly to requests & 3.86 & \\
\hline \multirow[t]{3}{*}{ Customization } & Interested in personal needs & 3.58 & .82 \\
\hline & Customization appeals to me & 3.90 & \\
\hline & Satisfied with personalization & 3.71 & \\
\hline \multirow[t]{2}{*}{ Assurance } & Handling of personal information & 4.49 & .84 \\
\hline & Feel secure & 4.40 & \\
\hline \multirow[t]{2}{*}{ Online Satisfaction } & Overall satisfied with online customer service & 4.23 & .86 \\
\hline & Grade online customer service on scale 1-7 & 4.28 & \\
\hline \multirow[t]{3}{*}{ Online Value } & Provider offers high value online services & 3.70 & .87 \\
\hline & Time using online services is well spent & 3.27 & \\
\hline & Online services add value to total offer & 3.68 & \\
\hline \multirow[t]{3}{*}{ Online Enjoyment } & Enjoy surfing customer service website & 3.56 & .72 \\
\hline & Feel comfy using online services & 4.34 & \\
\hline & Using online customer service is frustrating (recoded) & 4.71 & \\
\hline \multirow[t]{2}{*}{ Offline Satisfaction } & Very satisfied with communication service & 4.83 & .85 \\
\hline & Grade communication service on a scale $1-7$ & 4.91 & \\
\hline \multirow[t]{4}{*}{ Loyalty } & I would take this provider again, & 4.58 & .93 \\
\hline & I recommend my provider to others & 4.29 & \\
\hline & I prefer my provider above others & 4.46 & \\
\hline & I intend to continue using my provider & 4.61 & \\
\hline
\end{tabular}


Table 2: Service Providers in the Survey

\begin{tabular}{lllc}
\hline Provider & Country & Website & Respondents \\
\hline Ben & Netherlands & www.ben.nl & 8 \\
Dutchtone & Netherlands & www.dutchtone.nl & 19 \\
KPN & Netherlands & www.kpn.com & 11 \\
Libertel* & Netherlands & www.libertel.nl & 30 \\
Telfort** & Netherlands & www.telfort.nl & 16 \\
D1 & Germany & www.t-d1.de & 7 \\
D2 & Germany & www.d2vodafone.de & 9 \\
E-plus & Germany & www.e-plus.de & 8 \\
Viag-Interkom & Germany & www.viag-interkom.de & 8 \\
Proximus & Belgium & www.proximus.be & 2 \\
\hline & & Total: & 118 \\
\hline
\end{tabular}

*Currently: Vodafone ** Currently: $\mathrm{O}_{2}$ 
Table 3: Correlation Matrix of Major Constructs*

\begin{tabular}{|c|c|c|c|c|c|c|c|c|c|}
\hline & Loy & OfflSat & OnISat & Enjoy & Value & Usabil & Escape & Resp & Cust \\
\hline Loyalty & 1 & & & & & & & & \\
\hline Offline Satisfaction & .662 & 1 & & & & & & & \\
\hline Online Satisfaction & .551 & .516 & 1 & & & & & & \\
\hline Online Affect & .464 & .429 & .552 & 1 & & & & & \\
\hline Online Value & .520 & .414 & .713 & .579 & 1 & & & & \\
\hline Usability & .460 & .314 & .545 & .709 & .512 & 1 & & & \\
\hline E-scape & .410 & .171 & .524 & .600 & .488 & .711 & 1 & & \\
\hline Responsiveness & .707 & .434 & .562 & .450 & .568 & .457 & .357 & 1 & \\
\hline Customization & .584 & .446 & .583 & .564 & .692 & .518 & .618 & .664 & 1 \\
\hline Assurance & .423 & .306 & .373 & .378 & .391 & .270 & .346 & .422 & .464 \\
\hline
\end{tabular}

*All correlations are significant at the .01 level, except the correlation between e-scape and offline satisfaction, which is non-significant. 
Table 4: Model Fit Statistics

\begin{tabular}{llll}
\hline Eq. & d.f. & F-value (P-value) & $\mathbf{R}^{2}$ adjusted \\
\hline $\mathbf{1}$ & $2 ; 106$ & $44.76(<0.0001)$ & 0.45 \\
$\mathbf{2}$ & $2 ; 106$ & $51.88(<0.0001)$ & 0.49 \\
$\mathbf{3}$ & $3 ; 105$ & $54.54(<0.0001)$ & 0.60 \\
$\mathbf{4}$ & $2 ; 106$ & $54.46(<0.0001)$ & 0.50 \\
& System d.f. $=423$ & & System weighted $\mathrm{R}^{2}=0.60$ \\
\hline
\end{tabular}


Table 5: Empirical Results

\begin{tabular}{llllll}
\hline $\mathrm{P}$ & Relationship & Coefficient & T-value & P-value & Conclusion \\
\hline $\mathrm{P}_{1}$ & OFFL_SAT $\rightarrow$ LOYALTY & 0.61 & 6.49 & $<0.0001$ & Results support $\mathrm{P}_{1}$ \\
$\mathrm{P}_{2}$ & ONL-SAT $\rightarrow$ LOYALTY & 0.54 & 5.83 & $<0.0001$ & Results support $\mathrm{P}_{2}$ \\
$\mathrm{P}_{3}$ & ONL_VALUE $\rightarrow$ ONL_SAT & 0.46 & 5.96 & $<0.0001$ & Results support $\mathrm{P}_{3}$ \\
$\mathrm{P}_{4}$ & ONL_ENJOY $\rightarrow$ ONL_SAT & 0.35 & 3.72 & 0.0003 & Results support $\mathrm{P}_{4}$ \\
$\mathrm{P}_{5}$ & USABILITY $\rightarrow$ ONL_ENJOY & 0.19 & 1.89 & 0.0610 & Results support $\mathrm{P}_{5}$ \\
$\mathrm{P}_{6}$ & E-SCAPE $\rightarrow$ ONL_ENJOY & 0.55 & 5.35 & $<0.0001$ & Results support $\mathrm{P}_{6}$ \\
$\mathrm{P}_{7}$ & CUSTOM $\rightarrow$ ONL_VALUE & 0.79 & 8.90 & $<0.0001$ & Results support $\mathrm{P}_{7}$ \\
$\mathrm{P}_{8}$ & ASSUR $\rightarrow$ ONL_VALUE & n.s. & n.s. & n.s. & Results do not support $\mathrm{P}_{8}$ \\
$\mathrm{P}_{9}$ & RESPONS $\rightarrow$ ONL_SAT & 0.22 & 3.86 & 0.0002 & Results support $\mathrm{P}_{9}$ \\
\hline
\end{tabular}


Figure 1: Conceptual Model

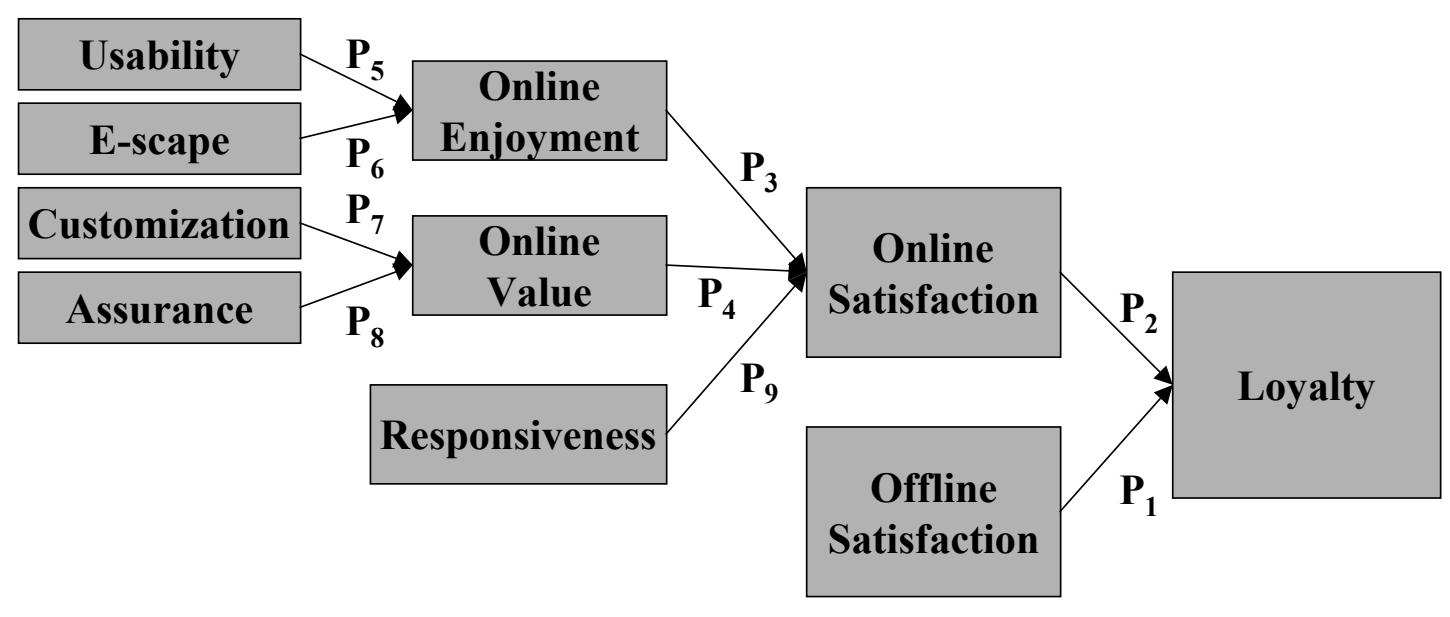


Figure 2: System of Equations

ONL_ENJOY $=\alpha_{1}+\beta_{1} U S A B I L I T Y+\beta_{2} E_{-} S C A P E+\varepsilon_{1}$
$O N L_{-} V A L U E=\alpha_{2}+\beta_{3} C U S T O M+\beta_{4} A S S U R+\varepsilon_{2}$
$O N L_{-} S A T=\alpha_{3}+\beta_{5} O N L_{-} E N J O Y+\beta_{6} O N L_{-} V A L U E+\beta_{7} R E S P O N S+\varepsilon_{3}$
LOYALTY $=\alpha_{4}+\beta_{8} O N L_{-} S A T+\beta_{9} O F F L_{-} S A T+\varepsilon_{4}$

